\title{
Sistem Informasi Pemesanan Makanan Berbasis Client Server di Kopi We Salatiga
}

\author{
Narendra Basral Naseri ${ }^{\mathrm{a}, 1, *}$, Nurgiyatna ${ }^{\mathrm{b}, 2}$ \\ ${ }^{\text {ab }}$ Fakultas Komunikasi dan Informatika, Universitas Muhammadiyah Surakarta, Jl.Ahmad Yani, Pabelan, Kartasura, Sukoharjo 57162, Indonesia \\ ${ }^{1}$ rendranaseri@gmail.com *; ${ }^{2}$ nurgiyatna@ums.ac.id;; \\ * Koresponsendi penulis
}

ARTICLE INFO

Article history

Menerima 7 April 2021

Revisi 4 Mei 2021

Diterima 17 Mei 2021

Kata Kunci

Client Server

Makanan

Pemesanan

Sistem Informasi

Tranksaksi

\section{ABSTRACT}

Many entrepreneurs have formed businesses in the culinary field. At this time, there are many restaurants not use computerization in making transactions. With limited human resources and lack of time effectiveness to serve customers who place orders, a food ordering information system that can solve these problems. This system makes it easy to order food and manage the incomes because when making transactions with customers you don't need to write menus manually and customers can get correct info. In This system, customers immediately know the details of their transactions. This study uses the Waterfall method then built with the CodeIgniter's framework and as database support using MySQL. The data collection stage in making this information system explain out by observation and interview. The system will be applied with a client-server network architecture using a personal computer at the cashier as a server, so the system runs without internet access. The results of this system include ordering menus, processing order and transaction data, and printing transaction receipts in PDF. System testing using the Black-Box testing method shows that the system has run well without any errors. Meanwhile, the results of questionnaire testing of 31 respondents, consisting of 30 visitors getting an interpretation percentage of $96 \%$ and 1 coffee shop owner getting $80 \%$ of the interpretation percentage. So, it can be concluded that the system is considered can be done to be applied and facilitates the process of ordering food.

This is an open access article under the CC-BY-SA 4.0 license.

\section{Pendahuluan}

Makanan merupakan suatu kebutuhan primer manusia yang tidak bisa lepas dari kehidupan manusia. Berkembangnya perekonomian masyarakat mendorong tingkat kebutuhan makanan terus mengalami kenaikan yang signifikan, sehingga masyarakat meakukan berbagai cara untuk memenuhi kebutuhan. Salah satunya dengan memanfaatkan perkembangan teknologi informasi yang pesat untuk melakukan pemesanan menu di suatu tempat makan.

Banyak pengusaha kuliner yang menggunakan cara konvensional dalam melakukan transaksi pemesanan dan pembayaran, sehingga insfrastruktur jaringan yang tersedia belum dimanfaatkan dengan maksimal. Pemanfaatan insfrastruktur jaringan dalam usaha dibidang kuliner diantaranya, adalah terciptanya suatu sistem pemesanan makanan berbasis client server dapat diakses dengan smartphone pengunjung yang terhubung pada jaringan lokal, kemudian pesanan disajikan di meja pemesan. Untuk pemanfaatan teknoogi informasi yang tersedian saat ini diperlukan pembuatan sebuah sistem yang dapat menangani pemesanan makanan melalui dekstop dan mobile, namun sistem yang telah dikembangkan belum dapat menangani proses pembayaran dan hanya fokus pada 
fitur pemesanan [1]. Pemesanan adalah suatu aktifitas yang dilakukan oleh konsumen sebelum membeli maka, untuk mewujudkan kepuasan konsumen perusahaan harus mempunyai sebuah sistem pemesanan yang baik [2].

Kedai Kopi We saat ini terletak di Jl. Patimura No. 22, Salatiga. Kedai Kopi We merupakan kedai yang menyajikan berbagai jenis kopi dari seluruh pelosok nusantara serta menyediakan beberapa menu makanan ringan. Dalam kegiatannya Kedai Kopi We, data transaksi dan pemesanan masih dilakukan dengan konvensional, sehingga hal tersebut kurang efektif dan efisien serta resiko kesalahan dalam pemesanan, dan kesalahan penghitungan saat pembayaran. Menurut penelitian yang dilakukan oeh Hartanto pada tahun 2017 menjelaskan banyaknya jumlah barang yang dijual serta tingkat keramaian pembeli dapat mengakibatkan pelaku usaha kesulitan untuk mengelola dan menghitung transaksi penjualan secara cepat, tepat dan efisien [3].

Berdasarkan permasalahan diatas serta terbatasnya sumber daya manusia yang dimiliki Kedai Kopi We dapat menghambat pertumbuhan bisnis yang dijalani, sehingga diperlukan suatu sistem informasi untuk menunjang keterbatasan sumber daya manusia. Dalam implementasinya client server dipilih karena infrastruktur sudah tersedia dan kemudahan dalam pengoperasiannya. Untuk menunjang dalam bidang software menggunakan media website lokal karena mudah diakses oleh pelanggan dan penerapannya yang fleksibel sehingga dapat diakses melalui smartphone dan personal computer melalui browser. Penerapan website lokal karena faktor kemudahan perawatan dan keamanan yang lebih aman. Penggunaan sistem juga dapat membuat proses pemesanan dan pembayaran makanan menjadi lebih efektif dan efisien [4].

Mekanisme sistem secara ringkas yaitu, user sebagai customer yang berkunjung tidak perlu menulis pesanan secara manual, customer datang kemudian duduk pada meja yang diinginkan, membuka gadget atau smartphone lalu dihubungkan ke wifi yang tersedia maka akan langsung terbuka tampilan browser awal dari link mikrotik yang secara otomatis terbuka. Kemudian dapat melakukan pemilihan menu sesuai keinginan dan masukkan nama pemesan serta nomor meja saat pemesanan. Setelah melakukan pemesanan muncul checkout serta username dan password untuk melakukan akses internet yang disediakan pihak cafe. Kemudian sistem megirimkan data transaksi tersebut ke server, berikutnya data akan diterima oleh kasir. Setelah kasir menerima data transaksi kemudian mencetak data transaksi tersebut untuk menginformasikan pada juru masak. Pemilihan sistem harus disesuaikan dengan kebutuhan yang diperlukan oleh perusahaan [5].

\section{Metode}

Sistem Informasi Pemesanan Makanan Berbasis Client Server ini dikembangkan menggunakan metode waterfall. Metode waterfall merupakan pendekatan yang sistematis yang berurutan pada pengembangan perangkat lunak dengan spesifikasi kebutuhan yang memadai [6]. Metode Waterfall adalah suatu proses pengembangan perangkat lunak berurutan, di mana kemajuan dipandang sebagai terus mengalir ke bawah, (seperti air terjun) melewati fase-fase perencanaan, pemodelan, implementasi (konstruksi), dan pengujian [7].

\subsection{Analisis Kebutuhan}

Tahap ini merupakan awal dari metode Waterfall yang berfungsi sebagai landasan untuk melanjutkan ke proses selanjutnya. Tahap analisis berisi definisi tindakan perangkat untuk pengembangan [8]. Pada tahap ini diperlukan pemahaman tentang topik masalah guna mendapatkan solusi. Untuk menganalisis kebutuhan ini, diperoleh dengan observasi secara langsung serta wawancara dengan berbagai narasumber. Berdasarkan hasil observasi dan wawancara yang telah dilakukan, berikut adalah kebutuhan sistem yang diperlukan yaitu sistem berisi daftar menu dan harganya, sistem dapat menjalankan proses pemesanan yang dilakukan oleh customer, sistem dapat menyampaikan pesanan dari customer ke bagian kasir, sistem mampu mencetak laporan penjualan, sistem mampu menangani proses pembayaran.

\subsection{Perancangan}

Perancangan pada metode ini digunakan untuk merancang use case diagram, activity diagram, ERD dan rancangan interface sistem informasi pemesanan makanan berbasis client server. Untuk mengimplementasikan perancangan dibutuhkan observasi dan wawancara terhadap pemilik usaha, sehingga dapat mengelompokan hal diperlukan untuk merancang sistem ini. Untuk mendapatkan 
beberapa variabel diperlukan berbagai metode yang diperlukan dan akan diuraikan berdasarkan kebutuhan dengan penjelasan dibawah ini.

- Use Case Diagram

Usecase diagram digunakan untuk mengetahui fungsi apa saja yang ada di dalam sistem informasi dan siapa saja yang berhak menggunakan fungsi-fungsi tersebut [9]. Use Case Diagram menggambarkan interaksi hak akses antara aktor dengan sistem yang akan dirancang [10]. Tahap perancangan ini memberikan penjelasan bahwa kasir sebagai admin yang memiliki tanggung jawab atas segala hasil akhir yang berkaitan dengan sistem ini. Untuk merancang use case diagram memerlukan analisa yang tepat terhadap kebutuhan oleh setiap user. Gambaran dari Use Case Diagram ditunjukkan pada Fig. 1.

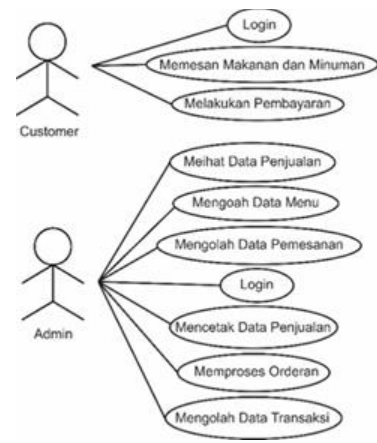

Fig. 1. Use Case Diagram

- Acitivity Diagram

Diagram ini menggambarkan aktivitas yang dijalankan pada sistem informasi berbasis web, seperti proses pengunjung melakukan pemesanan sampai dengan pencetakan struk pembayaran yang dilakukan oleh kasir. Ditunjukkan pada Fig. 2.

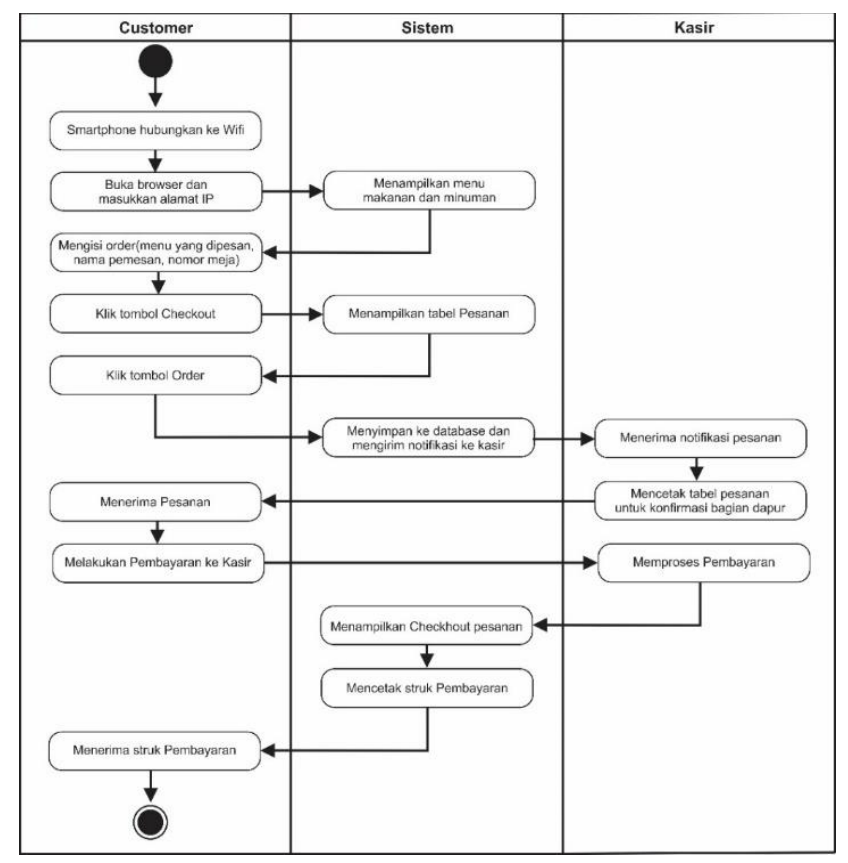

Fig. 2. Activity Diagram

- $\quad$ ERD (Entity Relationship Diagram)

ERD adalah model teknik pendekatan yang menyatakan atau menggambarkan hubungan suatu model [11]. Penelitian ini membutuhkan database yang dirancang menggunakan DB Designer, kemudian diimplementasikan pada database menggunakan MySQL. Database ini memiliki beberapa tabel yang saling terhubung maupun yang berdiri sendiri atau tidak memiliki relasi dengan tabel lain. Relasi antar tabel akan ditunjukkan pada Fig. 3. 


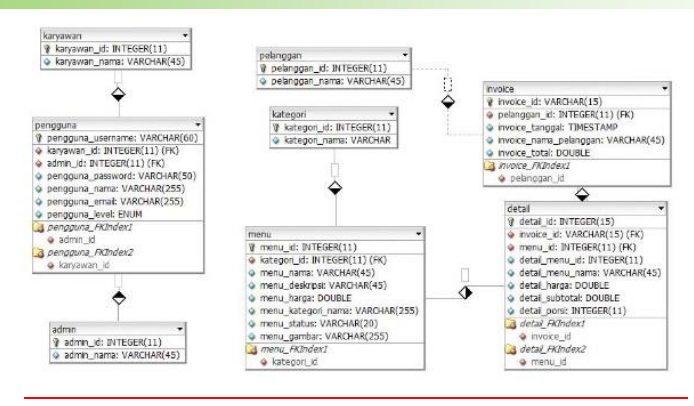

Fig. 3. ERD

- Arsitektur Jaringan

Pengembangan sistem informasi pemesanan makanan pada penelitian ini menggunakan konsep client-server. Client adalah pihak yang mengirimkan request untuk meminta resource ke server sedangkan server adalah pihak yang mengirimkan respon berupa data [12]. Dalam hal ini pembeli dapat mengakses sistem ini menggunakan smartphone maupun device lain yang bisa terkoneksi dengan jaringan wifi. Sistem ini dibangun menggunakan jaringan lokal yang terdapat pada cafe tersebut sehingga hanya customer yang bisa mengakses sistem ini. Untuk merancang ini diperlukan berbagai perangkat jaringan yang bisa menjalankan sistem, pada penelitian ini diperlukan Wireless Router untuk memancarkan sinyal dan menggabungkan berbagai jaringan antara internet dengan sistem yang dibangun. Selain Wireless Router diperlukan sebuah Personal Computer sebagai server yang berfungsi memproses data yang diminta oleh klien.

- Rancangan Tampilan

Rancangan tampilan sistem ini berbasis web karena banyak yang mengetahui jenis interface ini serta mudah untuk diterapkan ke masyarakat. UMKM (Usaha Mikro Kecil Menengah) saat ini banyak yang menerapkan sistem informasi berbasis web sebagai sarana untuk promosi produk yang dijual. Untuk membuat rancangan tampilan menggunakan aplikasi corel draw untuk membuat kerangka website yang akan dibangun. Rancangan halaman utama dari Sistem Informasi ini terdiri dari Menu untuk memesan makanan \& minuman yang ditunjukkan pada fig. 4. Tampilan dari Admin dan Kasir terdiri dari statistik penjualan, order terbaru, right sidebar serta total data penjualan, ditunjukkan dengan fig. 5 .

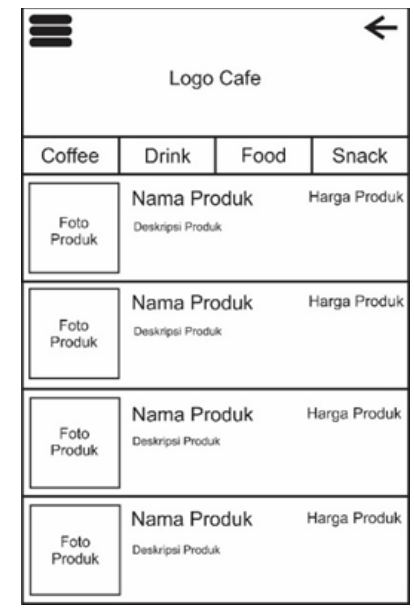

Fig. 4. Rancangan Order Makanan \& Minuman 


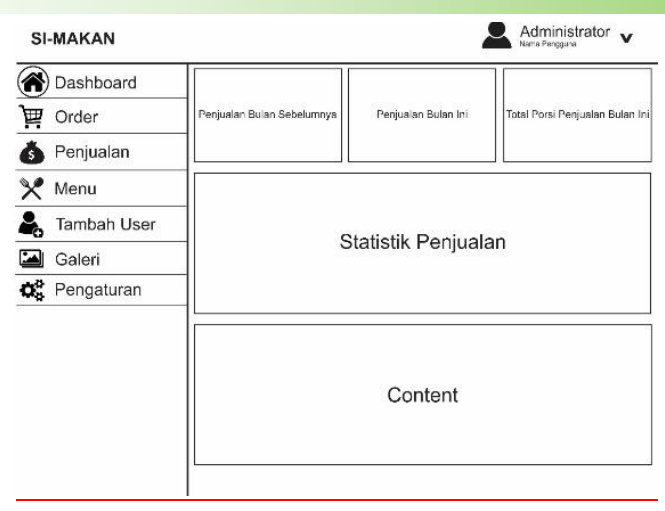

Fig. 5. Rancangan Administrator

\subsection{Pengembangan}

Dalam pengambangan sistem informasi ini dapat dilihat pada Gambar 2. Menggunakan sistem informasi berbasis website. Sistem informasi berbasis website dibangun dari awal dan diterapkan dengan jaringan berbasis client server. Sistem dibangun dengan framework codeigniter, menggunakan bahasa pemrogaman PHP dan MySQL sebagai Database Management System serta menggunakan Bootstrap untuk mengatur CSS.

Framework Codeigniter adalah sebuah tools yang digunakan untuk merancang sebuah website. Codeigniter menggunakan sebuah metode dalam penulisan script bernama query builder, dimana query builder tersebut memudahkan developer dalam penulisan script, selain memudahkan developer, sistem query builder juga berguna untuk server side, dimana query builder bisa terbaca di server mana saja. Selain itu juga terdapat library dalam codeigniter yang menyediakan fungsi- fungsi yang dapat dipanggil kapan saja [13].

\subsection{Pengujian}

Sistem informasi pemesanan makanan ini diperlukan 2 cara pengujian, yaitu Blackbox testing dan kuisioner. Pengujian aplikasi bertujuan untuk memperoleh produk yang berkualitas yang memberikan produktivitas tinggi, dimana kualitas aplikasi itu sendiri bergantung kepada kepuasan pelanggan atau pengguna [14].

- Pengujian Blackbox (Blackbox testing)

Pengujian blackbox digunakan untuk menguji fungsionalitas komponen/fungsi suatu sistem. Dalam pengujian di sistem informasi pemesanan makanan ini dilakukan pada penelitian ini meliputi uji saat customer melakukan proses pemesanan, uji menu seperti input data, view data dan mencetak nota pembayaran. Pengujian tersebut dilakukan agar sistem dapat berjalan dengan baik dan siap digunakan.

- Pengujian Kuisioner

Pada pengujian kuisioner dilakukan uji validitas dan realibilitas serta untuk mendapatkan respon dari pengguna tentang bagaimana sistem ini bekerja. Pada tahap ini akan dibutuhkan 3 responden yaitu customer dan pemilik kedai kopi.

\subsection{Implementasi}

Sistem informasi pemesanan makanan ini diimplementasikan dengan arsitektur client server yang hanya mencakup pada kedai kopi tersebut. Sistem ini dioperasikan tanpa adanya koneksi internet sehingga tidak terintregasi dengan layanan hosting. Pada tahap implementasi telah diperoleh data yang dikumpulkan sehingga dapat menjadi acuan untuk membangun sistem yang sudah dirancang. 


\section{Hasil dan Pembahasan}

\subsection{Hasil}

Implementasi pada hasil ini merupakan representasi dari metode waterfall yang diterapkan dimulai dari analisa kebutuhan hingga proses pembangunan sistem yang telah dirancang dan diusulkan. Pengembangan sistem dilakukan dengan framework Codeigniter dengan bahasa pemrogaman PHP dan MySQL sebagai database manajemen sistem. Sistem ini dibangun menerapkan konsep client server yang memanfaatkan jaringan yang tersedia. Terdapat pemisahan previlage atau hak akses untuk masing - masing user.

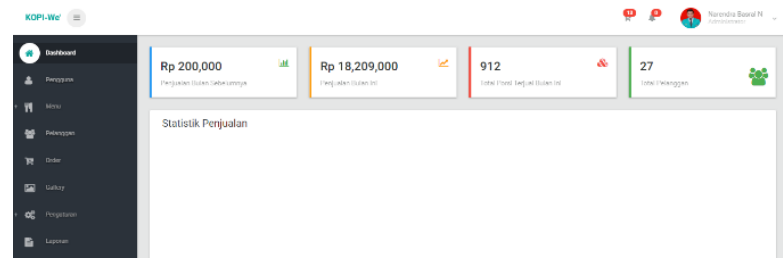

Fig. 6. Tampilan Dashboard Admin

Fig. 6 merupakan tampilan dashboard pada admin. Hanya karyawan cafe dan pemilik usaha yang dapat mengakses halaman ini. Untuk mengakses halaman ini admin harus melakukan session login terlebih dahulu. Pada halaman admin atau bisa juga disebut dengan backend ini digunakan untuk melakukan pengelolaan data di database yang meliputi update, insert dan delete data. Pada halaman admin juga terdapat fitur cetak laporan yang dapat digunakan untuk mencetak laporan penjualan.

- Halaman Order

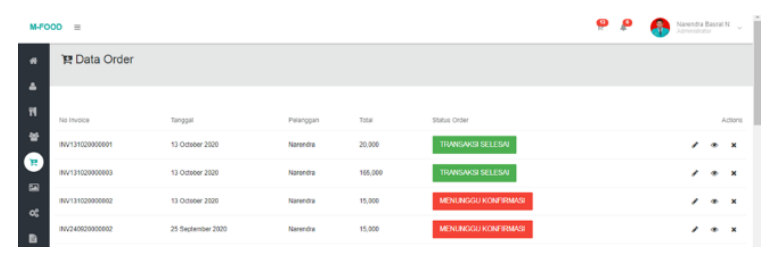

Fig. 7. Halaman Data Order

Pada halaman ini ditunjukan data pesanan yang masuk dari pelanggan. Pada halaman ini terdapat informasi yang berupa nomor invoice, tanggal, nama pelanggan, total, nomor meja, status order dan action yang terdapat 3 aksi yaitu mengupdate status order, menghapus dan melihat detail pesanan yang akan ditampilkan pada Fig. 8 .

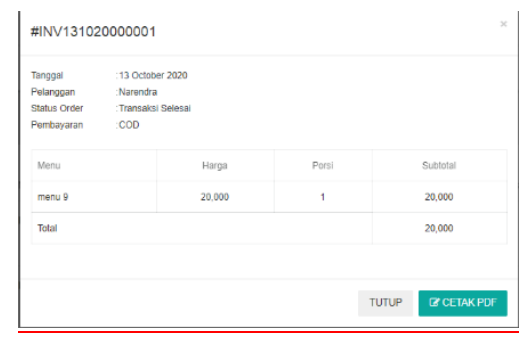

Fig. 8. Halaman Detail Pesanan

Fig. 8 menunjukan semua detail pesanan pelanggan. Halaman ini dibutuhkan karena karyawan cafe harus mengetahui detail dari pesanan untuk membuatan pesanannya. Halamain ini dibuat dengan tampilan yang simple agar karyawan dapat mudah memahami apa yang dipesan oleh pelanggan. Sehimgga meminimalisir kesalahan saat membuat pesanan. Kemudian dihalaman tersebuat ada tombol untuk mencetak struk ketika pelanggan melakukan pembayaran yang akan ditampilkan pada fig. 9 . 


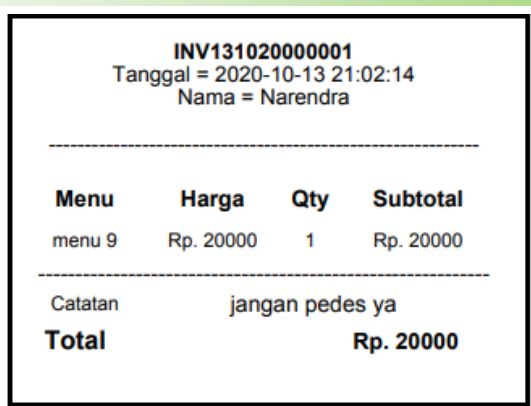

Fig. 9. Struk Pembayaran

Sistem akan mencetak struk yan ditunjukkan pada fig. 9 ketika pembayaran telah berhasil dan otomatis status order akan terupdate menjadi orderan selesai.

- Halaman Laporan Penjualan

Halaman ini menampilkan detail pendapatan perhari yang menampilakn berupa nama menu, harga menu, jumlah item terjual, pendapatan per item menu serta total pendapatan keseluruhan di hari itu. Halaman ini memudahkan karyawan dan pemilik usaha untuk mendapatkan detail pendapatan serta bisa dijadikan sebagai rekapan untuk mengetahui perkembangan usaha yang telah dijalankan. Halaman ini berformat PDF dan bisa di cetak menjadi hard copy. Dan Halaman Laporan Penjualan akan ditampilkan pada fig. 10.

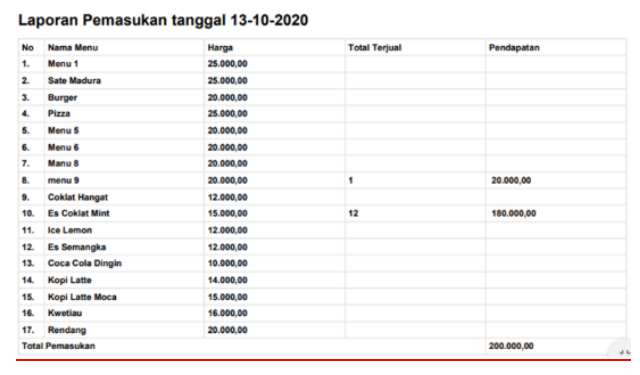

Fig. 10. Laporan Penjualan

- Halaman Menu

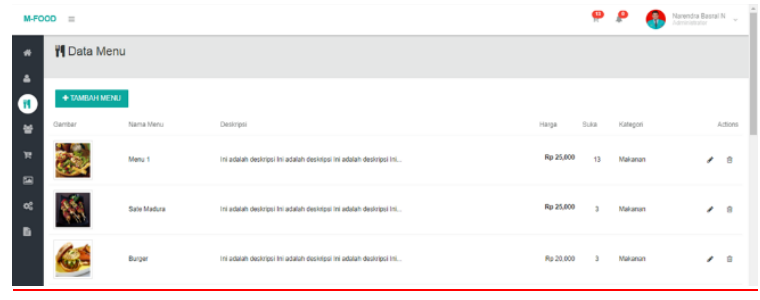

Fig. 11. Halaman Data Menu

Pada halaman tersebut berisi informasi tentang menu yang disediakan oleh cafe. Informasi yang bisa didapatkan pada halaman tersebut berupa foto menu, nama menu, deskripsi menu, harga, kategori menu serta ada kolom actions yang berisi 2 fitur yaitu mengedit data dan menghapus data. Selain itu ada juga fungsi untuk menambah menu baru. 


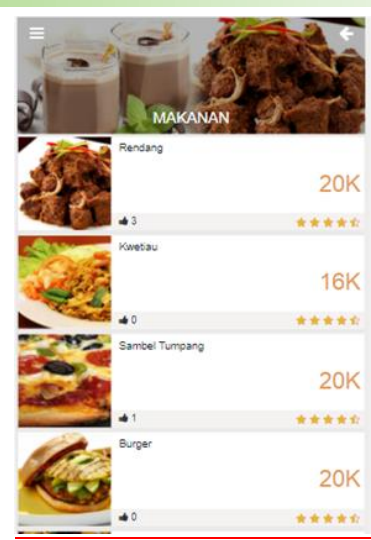

Fig. 12. Halaman Pemesanan Format Smartphone

Fig. 12 menampilkan halaman pemesanan yang berisi daftar menu makanan dan minuman beserta dengan harganya. Halaman ini didesain sangat responsif sehingga dapat menyesuaikan sesuai gadget pelanggan, sehingga pelanggan tidak menemukan kesuliatan ketika memesan makanan ataupun minuman melalui gadget yang dimiliki.

\subsection{Pembahasan}

Untuk menjalankan sistem ini pelanggan harus menghubungkan smartphone dengan jaringan wifi yang tersedia, setelah terhubung pelanggan bisa membuka browser dang memasukan url yang tersedia pada nomor meja maka akan terhubung pada sistem informasi. Kemudian pelanggan melakukan regristasi untuk pembuatan akun, setelah itu pelanggan akan ditujukkan dengan tampilan website yang terdiri dari kolom e-mail, nama dan password. Setelah melakukan regristasi akun selanjutnya pelanggan akan ditampilkan pada tampilan beranda dan terdapat sub menu yang berisi menu makanan dan minuman. Setelah memilih makanan dan minuman pelanggan diarahkan untuk mengisi jumlah menu yang akan dipesan setelah itu pelanggan pelanggan mendapatkan tampilan yang berisi setail pemesanan. Dan yeng terakhir pelanggan menekan tombol order untuk melakukan pemesanan dan data yang dikirim oleh pelanggan akan diterima oleh kasir. Setelah menerima data dari pelanggan maka kasir akan memproses notifikasi tersebut dan mencetak data pesanan di untuk diberikan kepada barista dan setelah pesanan jadi pelayan akan menyajikan ke pelanggan serta memberikan tagihan ke pelanggan terhadap menu yang telah dipesan. Setelah menerima pembayaran dari pelanggan pelayan akan menyerahkan uang ke kasir untuk mencetak struk dan mengupdate di sistem.

Untuk menguji validitas sistem diperlukan dua macam cara pengujian yaitu pengujian black box dan pengujian kuisioner. Pengujian ini berguna untuk meminimalisir kasalahan sistem dan mengoptimalkan kinerja sistem. Sebagai validitas pengujian maka dijelaskan dengan data yang sudah didapatkan senagai berikut:

\section{- Pengujian Black Box}

Sistem ini menggunakan pengujian dengan metode Black Box Testing. Metode Black Box Testing salah satunya digunakan untuk menguji perangkat lunak sumber terbuka yaitu Advance Trigonometry Calculator dan Personal Bank Account Manager (YAPBAM) [15]. Pengujian dilakukan guna memastikan bahwasanya sistem teah berjalan dengan baik serta meminimalisir kemungkinan adanya error maupun bug pada sistem. Dalam pengujian sistem penguji melakukan simulasi dengan 2 perangkat PC, 3 perangkat smartphone dan 1 perangkat router. PC 1 digunakan sebagai Web Server lalu PC 2 digunakan sebagai admin yang dioperasikan oleh karyawan cafe. Kemudian 3 perangkat smartphone digunakan untuk menguji halaman pemesanan makanan. Dan yang terakhir perangkat router digunakan untuk menghubungkan perangkat smartphone ke Web Server. Router juga berfungsi sebagai pengatur lalu lintas jaringan yang ada pada cafe tersebut, sehingga pemilik cafe dapat mengontrol penggunaan internet yang terdapat pada cafe tersebut .Hasil dari pengujian sistem ini dapat diihat pada tabel 1 . 
Table 1.

Hasil Pengujian Black BoX Testing

\begin{tabular}{|c|c|c|c|}
\hline Menu & Test Case & Harapan & Hasil \\
\hline \multirow{3}{*}{ Login } & $\begin{array}{c}\text { Masuk ke aplikasi dengan Username } \\
\text { dan Password benar. }\end{array}$ & Masuk ke halaman Dashboard. & Valid \\
\hline & $\begin{array}{c}\text { Masuk ke aplikasi dengan Username } \\
\text { dan Password salah. }\end{array}$ & $\begin{array}{c}\text { Muncul pesan "Username dan } \\
\text { Password salah". }\end{array}$ & Valid \\
\hline & $\begin{array}{c}\text { Masuk ke aplikasi dengan Username } \\
\text { saja tanpa menginput Password. }\end{array}$ & $\begin{array}{l}\text { Tidak bisa mensubmit button } \\
\text { login. }\end{array}$ & Valid \\
\hline Logout & Keluar dari aplikasi. & Masuk ke halaman Login. & Valid \\
\hline $\begin{array}{c}\text { Pesan } \\
\text { Makanan }\end{array}$ & Melakukan pemesanan makanan & $\begin{array}{c}\text { Pemesanan berhasil dan sistem } \\
\text { menuju ke halaman home } \\
\text { kembali. }\end{array}$ & Valid \\
\hline $\begin{array}{l}\text { Input Data } \\
\text { Menu }\end{array}$ & $\begin{array}{l}\text { Membuka halaman menu, } \\
\text { memasukan informasi kedalam form } \\
\text { lalu klik tambah. }\end{array}$ & Data masuk ke tabel menu. & Valid \\
\hline Upload Foto & $\begin{array}{l}\text { Mengupload foto pada halaman } \\
\text { galeri. }\end{array}$ & Foto Terupload. & Valid \\
\hline $\begin{array}{l}\text { Hapus Data } \\
\text { Menu }\end{array}$ & $\begin{array}{l}\text { Klik Hapus pada kolom action di } \\
\text { halaman menu. }\end{array}$ & Data terhapus dari tabel. & Valid \\
\hline $\begin{array}{c}\text { Proses } \\
\text { Pesanan }\end{array}$ & $\begin{array}{l}\text { Klik tombol berwarna merah pada } \\
\text { halaman } \text { order. }\end{array}$ & $\begin{array}{c}\text { Warna pada tombol berubah } \\
\text { status dan warna. }\end{array}$ & Valid \\
\hline Cetak Struk & $\begin{array}{l}\text { Klik tombol “cetak pdf” untuk } \\
\text { mencetak struk ke format PDF dan } \\
\text { mencetak ke bentuk hardcopy. }\end{array}$ & $\begin{array}{c}\text { Menampilkan struk dengan } \\
\text { format PDF lalu dicetak } \\
\text { menggunakan printer. }\end{array}$ & Valid \\
\hline C 1 & $\begin{array}{l}\text { Memilih tanggal lalu mencetak } \\
\text { laporan ke format PDF }\end{array}$ & $\begin{array}{l}\text { Berhasil menampilkan laporan } \\
\text { penjualan berdasarkan tanggal. }\end{array}$ & Valid \\
\hline Laporan & $\begin{array}{l}\text { Memilih taanggal berdasarkan } \\
\text { rentang tanggal. }\end{array}$ & $\begin{array}{l}\text { Berhasil menampilkan laporan } \\
\text { penjualan berdasarkan rentang } \\
\text { tanggal yang diinputkan }\end{array}$ & Valid \\
\hline
\end{tabular}

Terdapat 11 Fitur yang diuji yaitu login, logout, pesan makanan, input menu, upload foto, hapus menu, proses pesanan, cetak struk dan cetak laporan penjualan. Semua Test Case telah dijalankan dan menghasilkan hasil yang sesuai dengan yang diharapkan serta tidak ditemukan adanya kesalahan.

\section{- Pengujian Kuisioner}

Pengujian kuisioner digunakan untuk mengetahui penilaian calon pengguna terhadap sistem yang telah dibangun. Pengujian kuisioner dilakukan terhadap 30 responden pembeli dan 1 responden pemilik usaha. Hasil kuisioner ditunjukkan pada tabel 2 dan tabel 3.

Table 2. Hasil Kuisioner Pembeli

\begin{tabular}{cccccccc}
\hline \multirow{2}{*}{$\begin{array}{c}\text { Pernya- } \\
\tan \end{array}$} & \multicolumn{5}{c}{ Jumlah Jawaban } & Jumlah & Presentase \\
\cline { 2 - 5 } & SS & S & N & TS & STS & Skor & \\
\hline P1 & 26 & 2 & 2 & 0 & 0 & 144 & $96 \%$ \\
\hline P2 & 10 & 18 & 2 & 0 & 0 & 128 & $85.3 \%$ \\
\hline
\end{tabular}



Vol. 5, No. 1, Juli 2021, pp. 1-12

\begin{tabular}{cccccccc}
\hline P3 & 17 & 7 & 6 & 0 & 0 & 131 & $87.3 \%$ \\
\hline P4 & 19 & 9 & 2 & 0 & 0 & 137 & $91.3 \%$ \\
\hline P5 & 20 & 8 & 2 & 0 & 0 & 138 & $92 \%$ \\
\hline P6 & 21 & 7 & 2 & 0 & 0 & 139 & $92.6 \%$ \\
\hline \multicolumn{7}{c}{ Rata - Rata Presentase } & \\
\hline
\end{tabular}

Keterangan tabel 2 :

$\begin{array}{llll}\text { SS } & \text { : Sangat Setuju } & \text { TS } & \text { : Tidak Setuju } \\ \text { S } & : \text { Setuju } & \text { STS } & \text { : Sangat Tidak Setuju } \\ \text { N } & : \text { Netral } & & \end{array}$

Persamaan untuk perhitungan kuisioner adalah sebagai berikut:

Skor tertinggi $(\operatorname{Smax})=5 \times \mathrm{n}=5 \mathrm{n}(\mathrm{SS})$

Skor terendah $(\operatorname{Smin})=1 \times n=1 n(S T S)$

Dimana, $\mathrm{n}=$ jumlah responden.

Jumlah skor $(\mathrm{S})=\Sigma$ (total responden $\mathrm{x}$ bobot jawaban) (3)

Persentase Interprestasi $(\mathrm{PI})=$

Berikut contoh perhitungan pada pernyataan 1 pada kuisioner

Diketahui :

$$
\mathrm{n}=30 ; \operatorname{Smax}=(5 \times 30) ; \operatorname{Smin}=(1 \times 30)=30
$$

Pernyataan 1

$\mathrm{SS}(5)=26, \mathrm{~S}(4)=2, \mathrm{~N}(3)=2, \operatorname{TS}(2)=0, \operatorname{STS}(1)=0$

Jumlah skor $(S)=\sum(26+2+2+0+0)=144$

Maka, PI $=\frac{144 \times 100 \%}{150}=96 \%$

Table 3. Hasil Kuisioner Pemilik Usaha

\begin{tabular}{|c|c|c|c|c|c|c|c|}
\hline \multirow{2}{*}{$\begin{array}{c}\text { Pernya- } \\
\text { taan }\end{array}$} & \multicolumn{5}{|c|}{ Jumlah Jawaban } & \multirow{2}{*}{$\begin{array}{c}\text { Jumlah } \\
\text { Skor }\end{array}$} & \multirow{2}{*}{ Presentase } \\
\hline & SS & $\mathbf{S}$ & $\mathbf{N}$ & TS & STS & & \\
\hline $\mathrm{P} 1$ & 0 & 1 & 0 & 0 & 0 & 4 & $80 \%$ \\
\hline $\mathrm{P} 2$ & 1 & 0 & 0 & 0 & 0 & 5 & $100 \%$ \\
\hline P3 & 1 & 0 & 0 & 0 & 0 & 5 & $100 \%$ \\
\hline $\mathrm{P} 4$ & 1 & 0 & 0 & 0 & 0 & 5 & $100 \%$ \\
\hline P5 & 0 & 1 & 0 & 0 & 0 & 4 & $80 \%$ \\
\hline P6 & 1 & 0 & 0 & 0 & 0 & 5 & $100 \%$ \\
\hline
\end{tabular}

Dari hasil perhitungan kuisioner dengan responden pelanggan dapat disimpulkan bahwa pelanggan sangat setuju bahwa sistem ini layak diterapkan dibuktikan dengan hasil persentase interpretasi pada pernyataan mendapatkan skor persentase sebesar $92,6 \%$. Pelanggan juga sangat setuju bahwa sistem ini memudahkan untuk melakukan pemesanan makanan yang dibuktikan dengan hasil persentasi interpretasi sebesar $96 \%$ pada pernyataan 1 . Kemudian hasil perhitungan kuisioner dengan pemilik cafe juga memberikan hasil yang positif. Pemilik menganggap sistem 
telah sesuai dengan kebutuhan yang dibuktikan dengan hasil presentase pernyataan 5 yang memiliki persentase interpretasi sebesar $80 \%$, yang artinya pemilik sangat setuju. Selain itu pada pernyataan 6 yang berbunyi "Sistem layak diterapkan" pemilik menyatakan persetujuannya dengan persentase interpretasi $100 \%$.

\section{Kesimpulan}

Sistem informasi pemesanan makanan berbasis Client-Server ini sudah berhasil diselesaikan melalui beberapa tahapan mulai dari analisa, perancangan, pengembangan, pengujan dan implementasi. Dengan selesainya pembangunan sistem maka tujuan penelitian telah tercapai. Sistem juga sudah berjaan dengan baik dengan tidak ditemukannya error maupun bug saat pengujian blackbox. Berdasarkan pengujian kuisioner diperoleh persentase rata-rata 90,75\% untuk responden pelanggan serta 93,3\% untuk responden pemilik usaha. Hal tersebut menunjukan bahwa sistem dapat diterima dan diterapkan oleh pengguna.

\section{Daftar Pustaka}

[1] A. Nuzul, N. Hidayah, and H. Supriyono, "Sistem Pemesanan Menu Makanan Dan Minuman Rumah Makan Berbasis Website,” J. Insypro, pp. 1-8, 2019.

[2] Z. R. Saputri, A. N. Oktavia, L. S. Ramdhani, and A. Suherman, "Rancang Bangun Sistem Informasi Pemesanan Makanan Berbasis Web Pada Cafe Surabiku," J. Teknol. dan Inf., vol. 9, no. 1, pp. 66-77, 2019, doi: 10.34010/jati.v9i1.1378.

[3] A. Y. Hartanto, R. T. S. Kom, and M. Cs, "Rancang Bangun Aplikasi Sistem Informasi Pemesanan Makanan Berbasis Website Pada Depot Mie Bandung 77 Artikel Ilmiah Peneliti : Program Studi Teknik Informatika Fakultas Teknologi Informasi Universitas Kristen Satya Wacana Rancang Bangun Aplikasi Sistem I," pp. 1-19, 2017.

[4] P. N. M. Yawale, P. N. V Pardakhe, and P. M. A. Deshmukh, "Issn No : 2394-8442," Iaetsd J. Adv. Res. Appl. Sci., vol. 4, no. 7, pp. 92-96, 2017.

[5] I. K. Siahaan, "Informasi Pemesanan Menu Dengan Perangkat Nirkabel Pada Cafe Resto," J. Manaj. Sist. Inf., vol. 3, no. 2, pp. 1020-1029, 2018.

[6] D. H. Salsabiela, "Sistem Pemesanan Makanan Berkonsep Self-ordering Dan Berbasis Web Pada Rumah Makan," 2020.

[7] C. Tristianto, "PENGGUNAAN METODE WATERFALL UNTUK PENGEMBANGAN SISTEM MONITORING DAN EVALUASI PEMBANGUNAN PEDESAAN," Notes Queries, vol. 182, no. 23, p. 321, 2018, doi: 10.1093/nq/182.23.321-a.

[8] A. Alshamrani and A. Bahattab, "A Comparison Between Three SDLC Models Waterfall Model, Spiral Model, and Incremental/Iterative Model," IJCSI Int. J. Comput. Sci. Issues, vol. 12, no. 1, pp. 106-111, 2016;

[9] K. Kawano, Y. Umemura, and Y. Kano, "Field Assessment and Inheritance of Cassava Resistance to Superelongation Disease 1," Crop Sci., vol. 23, no. 2, pp. 201-205, 2016, doi: 10.2135/cropsci1983.0011183x002300020002x.

[10] T. N. Aini and S. T. Nurgiyatna, "Sistem Informasi Penjualan Sepeda Motor Bekas di Dealer Sinar Maju Motor Purwodadi," vol. 21, no. 01, pp. 1-9, 2020.

[11]T. M. Eka Wida Fridayanthie, "RANCANG BANGUN SISTEM INFORMASI PERMINTAAN ATK BERBASIS INTRANET," Eka Wida Fridayanthie , Tias Mahdiati, vol. 147, no. March, pp. 11-40, 2016.

[12] S. Gupta, S. Narang, S. Arora, and S. Jindal, “A Brief Discussion About Client-Server System,” Int. J. Adv. Res. Comput. Eng. Technol., vol. 6, no. 3, pp. 2278-1323, 2017.

[13]S. H. Basri, A. Izzuddin, and I. Marzuki, "Sistem Informasi Pelayanan Akademik Berbasis SMS Gateway Menggunakan PHP Framework CodeIgniter,” Energy, vol. 5, no. 1, pp. 20-23, 2016. 
[14] W. N. Cholifah, Y. Yulianingsih, and S. M. Sagita, "Pengujian Black Box Testing pada Aplikasi Action \& Strategy Berbasis Android dengan Teknologi Phonegap," STRING (Satuan Tulisan Ris. dan Inov. Teknol., vol. 3, no. 2, p. 206, 2018, doi: 10.30998/string.v3i2.3048.

[15] M. Nurudin, W. Jayanti, R. D. Saputro, M. P. Saputra, and Y. Yulianti, "Pengujian Black Box pada Aplikasi Penjualan Berbasis Web Menggunakan Teknik Boundary Value Analysis," J. Inform. Univ. Pamulang, vol. 4, no. 4, p. 143, 2019, doi: 10.32493/informatika.v4i4.3841. 